\title{
International Relations Theories and Turkish International Relations: Observations Based on a Book
}

\author{
Seçkin Köstem \\ McGill University
}

\section{Review article of:}

Ramazan Gözen, ed., Uluslararası İlişkiler Teorileri [International Relations Theories] (Istanbul: İletişim Yayınları, 2014, 648 pp., 37 TRY, paperback)

\section{Introduction}

International Relations (IR) theory is a fundamental course both at undergraduate and graduate levels of study in Political Science and/or International Relations departments in North America and Britain. One might even argue that in the hierarchy of IR scholarship, authors of IR theory rank high, if not always first, among their colleagues and that theorizing is a tough but charismatic business. International Relations Theories, released by a prestigious Turkish publishing house, is a clear indication that IR theory is now well-established within the Turkish IR community. The book's publication can also be interpreted as a sign that the discipline in Turkey is moving from the dominance of the Mülkiye (School of Government) or diplomatic history schools towards embracing grand theoretical debates in the wider field of IR. International Relations Theories is edited by Ramazan Gözen, a well-known IR professor currently teaching at Marmara University, and the author of various books and articles on globalization, security studies, and Turkish foreign policy. The book compiles writing by distinguished professors and graduate students from around Turkey.

This review essay has two components. I will first present a brief outline of the book. Second, I will discuss the place of IR theory within the Turkish IR community by investigating the sources of the lack of theorizing up to now in Turkish IR and offering solutions to overcome this problem. I will argue that, in this investigation, the search for moving beyond grand theoretical debates in favor of puzzle-driven research can be useful. Working with specific concepts and themes, I also argue, will enhance Turkey's contribution to IR theory. In addition, I call for diversifying the curriculum in IR departments, in which teaching theories, rather than theorizing, has become the disciplinary norm.

\section{Overview of the Book}

One remarkable aspect of the book is its comprehensiveness. In addition to discussing established and internalized IR theories such as Realism, Idealism, Liberalism, the English School, Constructivism, and Critical Theory, the book has chapters on International Political 
Theory, Marxism, Post-structuralism, Post-colonial theory, Feminist IR, and Green Theory. In that sense, the edited volume very well displays what leading scholars of IR theory have recently dubbed "theoretical proliferation." It also incorporates a sophisticated chapter (Chapter 1) on the philosophy of science, written by Faruk Yalvaç, which elaborates on the founding blocks of theorizing in social sciences and IR. Gonca Biltekin's Chapter 14, on homegrown theorizing and non-Western approaches to IR, is rich in terms of the literature it covers and opens the floor for discussion on what should be done to improve local theory development - a topic I will return to later in this review.

Each chapter discusses the application/implications of the theories for Turkey's international relations, which makes the book very important, especially for undergraduate and graduate students. Turkey's relations with the EU and NATO, and the "new" activism in Turkish foreign policy, are issue areas that many of the chapters address. For example, Gözen, in Chapter 2, shows through Turkey's Republican history that its foreign policy has been driven by Idealist principles and policies, such as Atatürk's "Peace at home, peace in the world," Turkey's bid for integration with the EU, and Özal's "peace pipelines" project. Similarly, in Chapter 3, Burak Bilgehan Özpek argues that the evolution of Turkey's relations with the EU confirms the Liberal theory's hypothesis that domestic political structures and interest groups influence foreign policy. In Chapter 7, Hakan Övünç Ongur and Başak Yavçan, on the other hand, interpret Turkey's relations with the EU from a Marxist perspective, and argue that the web of economic relations between the former and the latter resembles one between a peripheral country and the core, in which the former is economically dependent on the latter. Yet for Constructivists, Mustafa Küçük demonstrates in Chapter 9 that Turkey's relations with the EU can only make sense if one takes into account how Turkey's "Western" identity and national interests and the EU's interpretation of Turkey's identity have interacted and mutually constituted each other. From this point of view, Turkey became a member of NATO and has sought EU membership due mainly to its self-conception as a Western state. Similarly for Constructivists, the end of the Cold War revealed Turkey's multiple identities, which eventually paved the way for redefining its national interests. The re-formation of Turkey's foreign policy goals and interests under Justice and Development Party (JDP) governments can only be understood in this light. Conversely, in Chapter 4 Eyüp Ersoy shows that for a Realist, Turkey's "new" foreign policy makes perfect sense as it tries to adjust to an anarchic region rife with conflict and fierce rivalry. From this point of view, regardless of the JDP's ideological roots or the academic and intellectual background of Prime Minister Davutoğlu, the latter is a statesman who has been acting according to the principles of survival and self-help with a goal of maximizing Turkey's national interest. However, according to Tarık Oğuzlu (Chapter 5), from an International Political Theory perspective, Turkish foreign policy has become "value-oriented," with normative principles such as justice, human rights, and humanitarian intervention gaining primary status in the definition of Turkey's national interests.

Reading Turkey's relations with the US and NATO through Gramscian lenses, Mehmet Akif Okur and Hakan Övünç Ongur argue in Chapter 8 that Turkey's troubled relationship with American hegemony has been established through the interaction of ideas, material opportunities, and institutions. Drawing attention to the discursive construction of Turkey's 
new foreign policy in line with Post-structuralist theory, Tuncay Kardaş and Ramazan Erdağ argue in Chapter 10 that Davutoğlu's civilizational discourse can be interpreted as a response to Turkey's traditional status-quo-oriented and Westernist foreign policy. Similarly, recent debates on Turkey's 'axis shift' are, according to Kardaş and Erdağ, efforts to re-interpret Davutoğlu's discourse. Assessing Turkey's recent opening up to Africa through Post-colonial theory, Volkan İpek and Çağlar Oyman observe in Chapter 11 that Turkish foreign policy towards that continent differs depending on whether the region in question is North Africa or Sub-Saharan Africa. The Turkish interpretation of the former has been shaped by their common Ottoman past, as Turkey was the former imperial center. Conversely, Turkish decision-makers interpret Sub-Saharan Africa as a region in need of foreign aid, education, and economic development.

According to Mehmet Evren Eken's Feminist analysis (Chapter 12), Turkish foreign policy has traditionally been under the influence of a domestic masculine-militarist culture. In this light, depending on one's theoretical position, Turkey's involvement in the Syrian civil war can be interpreted as a continuation of masculine-militarist Realpolitik principles with a justificatory liberal discourse, or as human-centered foreign policy activism that prioritizes Syrian refugees and groups with different/oppressed identities. Yelda Erçandırlı, on the other hand, shows that Turkey's foreign policy goals have never been driven by 'Green politics'; in contrast, Turkey's policies vis-à-vis global climate change and sustainable development have only been tools to help Turkey acquire prestige in international organizations - such as gaining a temporary seat on the UN Security Council.

One major omission in Gözen's book is the lack of discussion on what kind of concrete thematic issues (or real-world problems) authors with different IR-theoretical backgrounds have written about. For example, Realists have focused on themes such as nuclear proliferation, the origins of war, and grand strategy, whereas Liberals from various strands have written on the institutional design of international organizations, the influence of sectoral interests on the formation of foreign economic policy, and incentives for economic cooperation. International Relations Theories would definitely be stronger had each chapter included a section on each theory's range of empirical contributions to the broader IR discipline. Considering the goal of the volume to become a textbook for undergraduate and graduate students, it would be helpful for such readers to be able to grasp the empirical and thematic issues that Realists, Liberals, Constructivists, and Critical theorists, for example, have debated, rather than just absorbing a summary of the grand theoretical questions. Such an inclusion would also show the reader that the same set of research questions and themes have been explained/studied differently by different theories.

This edited volume should open the door to similar books being published in Turkey that fall within the academic territory of IR, such as Foreign Policy Analysis, International Security, and International Political Economy. I believe theoretical discussions around a core theme such as regional integration, civil war, or climate change would also be very beneficial for such literatures in the Turkish language. An imminent example is Turkey's relations with the EU, which most authors of this edited volume have used to test/apply the theories they write about. A book on Turkey-EU relations with Realist, Liberal, Constructivist, Marxist, and other theoretical insights would help sharpen our minds and inform policy. Similarly, a book that brings together scholars with different theoretical insights on the JDP's foreign policy would also be very useful. 


\section{The State of Theory in Turkish IR: Problems and Prospects}

Turkish IR has obviously matured in the past few decades, and this change is not limited to the now-richness of literature on Turkish foreign policy. Scholars such as Rumelili ${ }^{2}$ and Zarakol ${ }^{3}$ have published leading pieces on self-other dynamics and stigmatization in international politics, respectively, which have contributed to the broader IR discipline through insights from Turkey. Similarly, I note Kayaoğlu's outstanding critique of "Westphalian Eurocentrism" in IR Theory ${ }^{4}$ as well as his book on extraterritoriality, which is based on British legal imperialism in Japan, the Ottoman Empire, and China. ${ }^{5}$

Yet these studies constitute a tiny minority in Turkish IR, which is still mostly focused on various regional and thematic aspects of Turkey's foreign relations, with little original theoretical insights. In 2008, Aydinli and Matthews asked the question, "Why is there still an underachievement of homegrown theorizing" in Turkey? ${ }^{6}$ The question still begs an answer. To be clearer, why - despite Turkey's position in a dynamic part of the world - do we still lack theoretical approaches based on the Turkish experience? I do not want to repeat what has already been said about this question; instead, let me state what I think is another major factor and problem that makes the above-cited question an enduring one. I argue that IR theorizing in Turkey by Turkish scholars is rare because now, in the post-Mülkiye era, our minds are occupied only with grand theories and meta-theoretical debates. We tend to think that theorizing means developing a theory as big and influential as that of Kenneth Waltz's Structural/Neo-Realism or Alexander Wendt's social theory of International Relations/ Constructivism. The side effects of importing theories from the Western core are twofold: we tend to either get lost in big theoretical questions as a result of the futile effort to explain all political phenomena with a single grand theory, or simply apply grand theories to issues of Turkey's international relations.

Unlike Comparative Politics, which emerged and has evolved mainly around methodological differences (quantitative vs. qualitative, large-N vs. case studies), IR has "largely been understood through the prism of the 'great debates," "' and incorporated serious ontological and meta-theoretical dividing lines. Contrary to the prevalence of diplomatic history and international law in the Mülkiye tradition, IR departments whose curricula are influenced by North American or British systems tend to prioritize teaching theory without empirics. Thus, an undergraduate IR student who undergoes such training, for example, would have to learn what Realism is before understanding the complexities of nuclear strategies, terrorist and anti-terrorist tactics, the function of the WTO or the history of Turkish-Russian relations. This method of teaching IR theories in Turkey results in graduate students and junior academics interpreting all research questions, puzzles, and thematic issues of realworld international and global politics within dogmatic grand-theoretical lenses. As a former

\footnotetext{
2 Bahar Rumelili, "Constructing Identity and Relating to Difference: Understanding the EU's Mode of Differentiation," Review of International Studies 30, no. 1 (January 2004): 27-47.

Ayşe Zarakol, After Defeat: How the East Learned to Live with the West (Cambridge, New York: Cambridge University Press, 2011); Ayşe Zarakol, "What Made the Modern World Hang Together: Socialisation or Stigmatisation?," International Theory 6, no. 2 (July 2014): 311-32.

4 Turan Kayaoğlu, "Westphalian Eurocentrism in International Relations Theory," International Studies Review 10 (2010): 193-217.

Turan Kayaoğlu, Legal Imperialism: Sovereignty and Extraterritoriality in Japan, Ottoman Empire and China (Cambridge, New York: Cambridge University Press, 2010).

Ersel Aydınlı and Julie Matthews, "Periphery Theorising for a Truly Internationalised Discipline: Spinning IR Theory of Anatolia," Review of International Studies 34, no. 4 (October 2008): 693-712. 
graduate student in Turkey, I remember having conversations with my colleagues about which professor belonged to which theoretical school. We determined the affiliations of a few instructors, whose leanings were obvious, but continued our efforts to uncover the remaining theoretical secrets throughout graduate school.

While one Turkish student trained within the so-called Mülkiye tradition (if that even exists anymore) would know all the details of the 1974 Cyprus intervention, another Turkish student trained in the alternative method would interpret the Cyprus intervention from a theoretical perspective, with little knowledge of the facts. We need neither a student who gets lost in tiny historical details (which does little to understand/explain its origins and consequences), nor a student who knows nothing about the context in which the Cyprus intervention took place (but keeps 'theorizing' about why it occurred in a bipolar structure). What we need is a student who knows the relevant facts and who can develop theoretical arguments based on those facts.

As a Ph.D. student in Canada, I have enjoyed the opportunity to meet prestigious IR scholars from varied theoretical backgrounds (Realist, Liberal, Constructivist, Critical, and English School) and listen to their presentations and lectures - arguments I read in textbooks when I was studying in Turkey. I was particularly surprised that representatives of the Realist school would have friendly conversations with representatives of the Constructivist school, and moreover, challenge each other's research with mind-opening questions and constructive feedback. Because of the different approach to education in Turkey, this, I imagine, would have been impossible for me to grasp as a master's student there: a Realist and a Constructivist exchanging views in a friendly and productive manner!

One solution that Western (primarily North American) scholars have offered for the problem of prevalent paradigmatic or meta-theoretical wars in the discipline is theoretical pluralism, or bridge building. ${ }^{8}$ In simplest terms, theoretical pluralism involves bringing together insights from different theories to explain political complexities. According to Katzenstein and Sil - two champions of eclectic research in IR - "theoretical monism" had real-world costs because it undermined the scholarly effort to better explain international politics. ${ }^{9}$ According to Checkel, eclectic/pluralist studies have significantly contributed to our understanding of international institutions, normative theory, and civil wars. ${ }^{10}$ It is unfortunate that these debates did not make it into Gözen's book - though it is understandable given the problem in Turkish IR that I touched upon above. On the other hand, I am aware of the single unanswerable question in eclectic theorizing - how do ideational and material variables interact? Which comes prior? Yet this line of thought can still offer a new venue for Turkish IR scholars to develop stronger arguments in fields such as Turkish foreign policy, in which it is impossible to argue that only ideational or material factors are predominant.

\section{Some Ideas for Enhancing Original Contribution to IR Theory in Turkey}

What, then, are the prospects for original contribution to IR theory in Turkey? More importantly, what should be done to encourage homegrown IR theories? In Chapter 14, Biltekin offers

\footnotetext{
8 In the past decade, much has been written with a pluralistic approach. For an overview of that literature, see Jeffrey Checkel, "Theoretical Pluralism in IR: Possibilities and Limits," in Handbook of International Relations, $2^{\text {nd }}$ Edition, ed. Beth A. Simmons, Thomas Risse, and Walter Carlsnaes (London: Sage Publications, 2013), 220-41.

9 Peter Katzenstein and Rudra Sil, Beyond Paradigms: Analytic Eclecticism in the Study of World Politics (New York: Palgrave Macmillan, 2010).

10 Checkel, "Theoretical Pluralism in IR," 220-41.
} 
several suggestions: First, IR scholars should build data - qualitative or quantitative - and present them to the broader Turkish IR community. Building data will help come up with original concepts. Second, the means through which concepts and data are shared with the broader community should be enhanced. Such methods include not only academic journals, but also workshops/conferences that will bring together scholars who focus on the same set of questions to form a research program over time. Finally, Turkish students and scholars should be familiar not only with Western political theory but also with non-Western/Turkish political theory and the history of thought. It is no secret that the major IR theories the book deals with all have ideational roots in Western philosophy, and all chapters touch upon this fact. In summary, for Biltekin, scholars with solid philosophical knowledge (including political philosophy and the philosophy of science) and are advanced in various data gathering and analysis techniques are necessary for the emergence of homegrown theories in Turkey.

While Biltekin investigates the prospects for homegrown theorizing, I am curious about how Turkish IR scholars' contributions to IR theory could be enhanced. I call for a puzzleor problem-driven approach, which prioritizes concept building based on local experience and sophistication based on methodology. Puzzle-driven research refers to starting scientific inquiry by focusing on real-world problems that cannot be explained/understood with existing theories. Turkey's engagement with the Western international system and the country's multi-regional character would enable finding many empirical puzzles and related research questions. In that light, Turkish IR scholars - especially young academics - should stop starting their research with grand-theoretical boundaries. While we should pursue "theory-led and theory-concerned" 11 research, we should not let grand theoretical debates block our vision. As Rumelili's ${ }^{12}$ survey of the East's agency in IR clearly demonstrates, Turkish scholars (as well as scholars from other non-core countries) will be able to challenge existing theories by developing new concepts based not only on the Turkish (other country's) experience, but also by taking Turkey as an agent in Turkish-Western relations. This is one of the reasons why, for me, Turkish scholars are doing much better in Comparative Politics (a sub-field of political science that is unfortunately little known, studied, or taught in Turkish IR departments because IR is thought to be separate from all other social sciences) than Turkish IR scholars. A recent example is Aktürk's comparative study on the characteristics of different "regimes of ethnicity" and determinants of the change/transformation in these regimes. ${ }^{13}$ Another recent example is Aytaç and Öniş's article on the divergent strands of populism in Argentina (left of center) and Turkey (right of center). ${ }^{14}$ Puzzle- or problemdriven research necessitates moving beyond theoretical and methodological pre-commitments and embracing a pragmatic research approach; different research questions demand different methodologies and a single grand theory may not always be helpful in explaining complex social phenomena.

At the end of the day, International Relations is a branch of social sciences, and IR theories 'import' many insights from other fields. ${ }^{15}$ Two major examples include Waltz's

\footnotetext{
11 Dunne, Hansen, and Wight, "The End of International Relations Theory?," 420.

12 Bahar Rumelili, "Uluslararası İlişkiler Teorisinde Yerel-Görüşlülük ve Doğu’nun Özneselliği," Uluslararası İlişkiler 6, no. 3 (Fall 2009): 45-71.

13 Şener Aktürk, Regimes of Ethnicity and Nationhood in Germany, Russia, and Turkey (New York: Cambridge University Press, 2012).

${ }^{4}$ S. Erdem Aytaç and Ziya Öniş, "Varieties of Populism in A Changing Global Context: The Divergent Paths of Erdoğan and Kirchnerismo," Comparative Politics 47, no. 1 (October 2014): 41-59.

15 Dunne, Hansen, and Wight, "The End of International Relations Theory?," 413.
} 
micro-economic approach and Wendt's sociological approach. Therefore, IR curricula should include detailed courses on history, comparative politics, political economy, and sociology. More importantly, these courses should either be taught prior to (preferably) or at least simultaneously with courses on IR theory. At the same time, IR students should learn what scientific inquiry means and how it differs from journalism or think-tank (policy) analysis. According to Rumelili, conceptual innovation was the sole reason why Amitav Acharya's piece on the localization of international norms in Southeast Asia was the only article that appeared in International Organization - the discipline's leading journal - that was built ontologically on Eastern agency. This fact shows that we need IR scholars who are capable of theorizing - or at least developing - arguments with a conceptual basis. And that is impossible to do without knowing facts/empirics. I cannot imagine Ted Hopf writing his incredibly rich book on the social construction of foreign policy without a thorough knowledge of Russian language and history, as well as methodological sophistication. ${ }^{16}$ Similarly, without detailed empirical knowledge on Germany, France, and Britain, as well as on the international agreements that created the European Community, Andrew Moravcsik's Liberal account of European integration would offer little theoretical insight. As a starting point, I believe that Turkey's history holds numerous ideas on conceptual strength and contributions to IR theory. ${ }^{17}$ For example, how did the Ottomans interpret territoriality and sovereignty, and how do those concepts differ from the so-called Westphalian order? Similarly, does the non-existence of armed conflict between the Ottoman Empire (Turkey) and the Safavid Empire (Iran) since 1639 tell us anything from an IR theory perspective? These are just two immediate questions that I can think of.

Notwithstanding my above arguments, I am also aware that for the majority of undergraduate IR students, getting a secure job in the private sector or the Turkish bureaucracy (Ministry of Foreign Affairs, Ministry of Economy, etc.) is much more important than learning IR theories. It is exactly for this reason that detailed reading and writing on grand theoretical discussions should be left to graduate studies. To conclude, while theorizing is good, theorizing for the sake of theorizing is a big danger, and is against the very nature of scientific inquiry. It is time to connect our theoretical maturity with empirical knowledge.

16 Ted Hopf, Social Construction of International Politics: Identities and Foreign Policy, Moscow, 1955 and 1999 (Ithaca: Cornell University Press, 2002).

17 Andrew Moravcsik, The Choice for Europe: Social Purpose and State Power from Messina to Maastricht (Ithaca: Cornell University Press, 1998). 


\section{Bibliography}

Aktürk, Şener. Regimes of Ethnicity and Nationhood in Germany, Russia, and Turkey. New York: Cambridge University Press, 2012.

Aydınl, Ersel, and Julie Matthews. "Periphery Theorising for a Truly Internationalised Discipline: Spinning IR Theory of Anatolia." Review of International Studies 34, no. 4 (October 2008): 693-712.

Aytaç, S. Erdem, and Ziya Öniş. "Varieties of Populism in a Changing Global Context: The Divergent Paths of Erdoğan and Kirchnerismo." Comparative Politics 47, no. 1 (October 2014): 41-59.

Checkel, Jeffrey. "Theoretical Pluralism in IR: Possibilities and Limits." In Handbook of International Relations, $2^{\text {nd }}$ Edition, edited by Beth A. Simmons, Thomas Risse, and Walter Carlsnaes, 220- 41. London: Sage Publications, 2013.

Dunne, Tim, Lene Hansen, and Colin Wight. "The End of International Relations Theory?" European Journal of International Relations 19, no. 3 (September 2013): 405-25.

Hopf, Ted. Social Construction of International Politics: Identities and Foreign Policy, Moscow, 1955 and 1999. Ithaca: Cornell University Press, 2002.

Kayaoğlu, Turan. Legal Imperialism: Sovereignty and Extraterritoriality in Japan, Ottoman Empire and China. Cambridge, New York: Cambridge University Press, 2010.

--- . "Westphalian Eurocentrism in International Relations Theory." International Studies Review 10 (2010): 193217.

Katzenstein, Peter, and Rudra Sil. Beyond Paradigms: Analytic Eclecticism in the Study of World Politics. New York: Palgrave Macmillan, 2010.

Moravcsik, Andrew. The Choice for Europe: Social Purpose and State Power from Messina to Maastricht. Ithaca: Cornell University Press, 1998.

Rumelili, Bahar. "Constructing Identity and Relating to Difference: Understanding the EU's Mode of Differentiation." Review of International Studies 30, no. 1 (January 2004): 27-47.

--- . "Uluslararası İlişkiler Teorisinde Yerel-Görüşlülük ve Doğu'nun Özneselliği.” Uluslararası İlişkiler 6, no. 3 (Fall 2009): 45-71.

Zarakol, Ayşe. After Defeat: How the East Learned to Live with the West. Cambridge, New York: Cambridge University Press, 2011.

--- . "What Made the Modern World Hang Together: Socialisation or Stigmatisation?" International Theory 6, no. 2 (July 2014): 311-32. 